\title{
EVALUASI SISTEM PEGENDALIAN INTERNAL TERHADAP PENGELOLAAN DANA KAS DI LEMBAGA PERKREDITAN DESA (LPD) DESA PAKRAMAN ANTURAN
}

\author{
Kadek Indri Yani Giri' Ni Luh Putu Sukma Wello Sari, \\ I Kadek Dwi Perdana, Putu Listia Ika Wardani \\ Jurusan Akuntansi, Universitas Pendidikan Ganesha, Singaraja, Bali, Indonesia
}

\begin{abstract}
Abstrak
Penelitian ini bertujuan untuk mengetahui sistem pegendalian internal terhadap pengelolaan dana kas di Lembaga Perkreditan Desa (LPD) Desa Pakraman Anturan. Penelitian ini menggunakan metode kualitatif, dengan sumber data yang digunakan adalah data primer. Dalam penelitian ini teknik pengumpulan data yaitu Observasi, Wawancara, dan Dokumentasi yang dilaksanakan di Lembaga Perkreditan Desa (LPD) Desa Pakraman Anturan. Dari hasil penelitian ini maka, sistem pengendalian internal di LPD Desa Pakraman Anturan dengan cara mengikuti aturan yang ada yaitu SOP (Standar Operasional Prosedur) dan dengan selalu memperhatikan koordinasi mengenai tugas masing-masing karyawan. Kemudian kas yang diterima dari berbagai kalangan (menabung, deposit, dan lainnya) tersebut dikelola dengan baik, dimana $75 \%$ dijadikan dalam bentuk kredit, $25 \%$ dijadikan cadangan likuiditasnya, diantaranya $20 \%$ ditempatkan di bank dan $5 \%$ dijadikan cadangan untuk pembiayaan-pembiayaan seperti biaya operasional.
\end{abstract}

Kata kunci: Pengendalian, Pengelolaan, Lembaga Perkreditan Desa

\begin{abstract}
This study aims to determine the internal control system for cash fund management in the Village Credit Institution (LPD) Desa Pakraman Anturan. This study uses qualitative methods, with the source of data used is primary data. In this study data collection techniques namely Observation, Interview, and Documentation carried out at the Village Credit Institution (LPD) Desa Pakraman Anturan. From the results of this study, the internal control system in LPD Desa Pakraman Anturan by following the existing rules, namely SOP (Standard Operating Procedure) and by always paying attention to the coordination of the duties of each employee. Then the cash received from various groups (saving, deposit, etc.) is well managed, where $75 \%$ is made in the form of credit, $25 \%$ is used as liquidity reserves, including $20 \%$ placed in banks and $5 \%$ used as reserves for financing such as operating costs.
\end{abstract}

\section{Keywords : Control, Management, Village Credit Institutions}

\section{Pendahuluan}

Negara Indonesia merupakan salah satu negara yang sedang berkembang, diantaranya dalam bidang perekonomian. Berkembangnya perekonomian yang tumbuh cepat dalam era globalisasi dan usaha pemerintah memperluas partisipasi aktif masyarakat 
di dunia usaha dalam bentuk pembangunan, menyebabkan peranan swasta yang bergerak di bidang jasa maupun dagang berkembang pesat, sehingga dapat menyerap tenaga kerja dan dapat mengurangi pengangguran. Salah satu upaya masyarakat untuk membantu pemerintah dalam pembangunan nasional dan mengurangi pengangguran adalah membangun atau mendirikan suatu usaha baik di bidang jasa maupun di bidang dagang. Dalam membangun atau mendirikan suatu usaha tentu saja membutuhkan modal yang cukup besar.

Peran LPD (Lembaga Perkreditan Desa) sangatlah penting dalam meminjamkan modal kepada masyarakat untuk mengembangkan suatu usaha. Berbagai kalangan masyarakat yang memperhatikan perekonomian di Bali berharap agar perekonomian Bali kedepannya mampu lebih memanfaatkan potensi lokal di dalam membangun perekonomian Bali. Di masa yang akan datang perekonomian Bali diharapkan tidak terlalu tergantung terhadap sektor pariwisata atau pada dunia luar. Melihat pertumbuhan dan perkembangan perekonomian di daerah pedesaan masih tergolong kecil, maka dari itu didirikan suatu Lembaga Perkreditan Desa (LPD). Lembaga Perkreditan Desa (LPD) merupakan salah satu kebijakan pemerintah Daerah Bali di dalam upaya menyalurkan bantuan permodalan kepada masyarakat desa di Bali. Menurut Peraturan Daerah Provinsi Bali Nomor 3 Tahun 2007, LPD merupakan badan usaha keuangan milik desa yang melaksanakan kegiatan usaha di lingkungan desa dan untuk krama desa. Kegiatan utama Lembaga Perkreditan Desa (LPD) adalah menghipun dana masyarakat berupa tabungan dan deposito, dan menyalurkan kembali kepada masyarakat yang membutuhkan dana pinjaman atau kredit. Mengingat pentingnya peranan dari Lembaga Perkreditan Desa (LPD) dalam perekonomian di pedesaan, maka LPD ditopang dengan administrasi dan pembukuan yang teratur. Dengan melihat program keuangan khususnya neraca dan laporan rugi/laba dapat diketahui kondisi keuangan LPD yang bersangkutan. Dengan kondisi keuangan yang baik maka menumbuhkan kepercayaan masyarakat terhadap LPD yang bersangkutan. Salah satu LPD yang memiliki kondisi keuangan yang baik adalah LPD Desa Pakraman Anturan, Kecamatan Buleleng. LPD ini mendapatkan julukan sebagai LPD yang sehat ditahun 2018.

Untuk membantu masyarakat, LPD Desa Pakraman Anturan memberikan pelayanan yang maksimal dan berusaha memberdayakan ekonomi dengan melaksanakan usaha yang mengutamakan pelayanan kepada usaha kecil menengah, serta memberikan keuntungan dan manfaat yang optimal kepada pihak-pihak yang berkepentingan sebagai usaha pokok dalam menjalankan usaha sacara baik. Dengan demikian, hadirnya LPD Desa Pakraman Anturan di tengah-tengah masyarakat memiliki andil dan bangkitnya perekonomian mereka, karena pada dasarnya fungsi dari lembaga keuangan adalah sebagai agent of development yang menyediakan jasa-jasa keuangan. Untuk menghindari adanya hal-hal yang tidak diinginkan terutama pada kondisi keuangan, LPD Desa Pakraman Anturan berusaha menjaga kondisi keuangan dengan cara pengendalian kas yang professional. Kas merupakan laporan keuangan yang memperlihatkan pengaruh aktivitas-aktivitas operasi, pendanaan, Pengawasan atas penerimaan kas yang berasal dari tabungan atau deposito, merupakan hal yang penting akan tetapi kecurangan atau penyelewengan biasanya jarang terjadi melalui transaksi penerimaan kas, melainkan melalui pengeluaran kas. Oleh karena itu pengawasan atas pengeluaran kas sama pentingnya atau bahkan kadang-kadang lebih penting daripada penerimaan kas Simamora (dalam Sumurung, 2015). 
Peraturan Pemerintah Republik Indonesia No. 60 Tahun 2008, sistem pengendalaian internal adalah proses yang integral pada tindakan dan kegiatan yang dilakukan secara terus menerus oleh pimpinan dan seluruh pegawai untuk memberikan keyakinan memadai atas tercapainya tujuan organisasi melalui kegiatan yang efektif dan efesien, keandalan laporan keuangan, pengamanan aset negara, dan ketaatan terhadap peraturan perundangundangan (Mamuaju, 2016). Pengawasan internal termasuk salah satu bagian dari pengendalian internal yang berfungsi melakukan penilaian independen atas pelaksanaan tugas dan fungsi instansi pemerintah.

Selain pengendalian kas diperlukan juga adanya pengendalian internal yang baik dalam penerimaan maupun pengeluaran kas. Pengendalian internal penerimaan kas merupakan pengendalian internal yang saling memisahkan fungsi antara pencatatan dan pengurusan kas yang jelas, dan bertujuan untuk menghindari penyelewenganpenyelewengan yang kemungkinan terjadi dalam perusahaan tidak dapat digelapkan oleh siapapun. Pada Lembaga Perkreditan Desa tentunya penting untuk diperhatikan sistem pengendalian internalnya agar tidak terjadi kecurangan dalam penerimaan maupun pengeluaran aliran kas. Sistem pengendalian internal berperan penting dalam menciptakan efisiensi dan produktivitas operasional, utamanya dalam mencapai tujuan institusi dan keberhasilan reformasi sektor publik (Zamzami, 2015). Hasil penelitian Altamuro dan Betty (Zamzami, 2015) menunjukkan perbaikan pengelolaan dan pelaporan pengendalian internal.

Berdasarkan latar belakang di atas, maka rumusan masalah dalam penelitian ini adalah "Bagaimana Sistem Pegendalian Internal Terhadap Pengelolaan Dana Kas Di Lembaga Perkreditan Desa (LPD) Desa Pakraman Anturan.

\section{Metode \\ Jenis Peneitian}

Penelitian merupakan suatu penyelidikan yang sistematis untuk meningkatkan sejumlah pengetahuan, juga merupakan suatu usaha yang sistematis dan terorganisasi untuk menyelidiki masalah tertentu yang memerlukan jawaban (Wikipedia, 2014). Pada penelitian ini menggunakan metode kualitatif. Penelitian kualitatif adalah penelitian tentang riset yang bersifat deskriptif dan cenderung menggunakan analisis. Dalam penelitian kualitatif peneliti bertolak dari data, memanfaatkan teori yang ada sebagai bahan penjelas, dan berakhir dengan suatu teori (Wikipedia, 2015). Penelitian kualitatif bertujuan untuk mencakup informasi tentang fenomena utama yang sedang dieksplorasi dalam suatu penelitian, partisipan penelitian, dan lokasi suatu penelitian (Ayo Nambah Ilmu.com, 2016).

\section{Sumber Data}

Berdasarkan sumbernya, data yang digunakan adalah data primer berupa hasil dari wawancara langsung dengan ketua LPD Desa Pakraman Anturan yang bernama Nyoman Arta Wirawan. Data primer adalah sumber data penelitian yang diperoleh secara langsung dari sumber aslinya yang berupa wawancara, jajak pendapat dari individu atau kelompok (orang) maupun hasil observasi dari suatu obyek, kejadian atau hasil pengujian (benda).

Selain data primer juga ada data sekunderyang digunakan dalam penelitian ini. Data sekunder adalah sumber data penelitian yang diperoleh melalui media perantara atau secara tidak langsung yang berupa buku, catatan, bukti yang telah ada, atau arsip baik yang dipublikasikan maupun yang tidak dipublikasikan secara umum. Dengan kata lain, peneliti membutuhkan pengumpulan data dengan cara berkunjung ke perpustakaan, pusat kajian, 
pusat arsip atau membaca banyak buku yang berhubungan dengan penelitiannya (kenaliinfo.web.id,2016).

\section{Waktu dan Lokasi Penelitian}

Penelitian ini dilaksanakan di Lembaga Perkreditan Desa (LPD) Desa Pakraman Anturan pada tanggal 9 Januari 2019 yang berlokasi di Jl. Raya Anturan No.16, Anturan, Kecamatan Buleleng, Kabupaten Buleleng, Bali 81119.

\section{Subjek dan Objek Penelitian}

Subjek dari penelitian ini adalah Lembaga Perkreditan Desa (LPD) Desa Pakraman Anturan. Sedangkan objek penelitian ini adalah sistem pengendalian internal terhadap pengelolaan dana kas.

\section{Teknik Pengumpulan Data}

\section{a. Observasi}

Observasi dalam penelitian ini dilakukan oleh peneliti dan pengamat. Observasi dalam penelitian ini adalah observasi langsung yaitu penelitian dan pengamat melihat dan mengamati secara langsung, kemudian mencatat perilaku dan kejadian yang terjadi pada keadaan sebenarnya. Observasi adalah instrumen yang sering dijumpai dalam penelitian pendidikan. Dalam observasi ini penelitian lebih banyak menggunakan salah satu dari panca indranya yaitu indra penglihatan.

b. Wawancara

Bentuk wawancara yang digunakan dalam penelitian ini adalah wawancara terstruktur. Wawancara Terstruktur, pewawancara menyampaikan beberapa pertanyaan yang sudah disiapkan pewawancara sebelumnya. Jadi wawancara terstruktur adalah wawancara yang dilakukan dengan terlebih dahulu menyiapkan pertanyaan dalam bentuk daftar-daftar.

c. Dokumentasi

Dengan menggunakan teknik dokumentasi peneliti berusaha untuk mendapatkan informasi dan data tertulis maupun bentuk gambar, foto, catatan, buku, dan lain sebagainya yang memiliki hubungan dengan masalah yang akan diteliti.

\section{Alat Pengumpulan Data}

Instrumen penelitian merupakan alat pada waktu peneliti menggunakan metode. Dalam penelitian ini menggunakan metode observasi, wawancara dan dokumentasi. Oleh sebab itu, instrumen yang dibutuhkan adalah pedoman observasi, pedoman wawancara, kamera serta alat tulis. Instrumen pada penelitian ini adalah peneliti itu sendiri (human instrumen) yang disertai alat bantu berupa kamera. Dalam penelitian kualitatif, peneliti mempunyai kedudukan sebagai perencana, pelaksana pengumpul data, analisis, penafsir, dan sebagai pelopor hasil peneliti.

\section{Hasil dan Pembahasan}

Sistem Pegendalian Internal Terhadap Pengelolaan Dana Kas Di Lembaga Perkreditan Desa (LPD) Desa Pakraman Anturan

Lembaga Perkreditan Desa (LPD) merupakan instansi yang sangat berperan penting dalam meminjamkan modal kepada masyarakat untuk mengembangkan suatu usaha. Ketua Kerta Desa Anturan, Made Suwinaya mengatakan 
"LPD bukan saja penggerak ekonomi lingkup di desa, tetapi keberadaanya berperan dalam membangkitkan perekonomian Bali. Untuk itu, pembinaan termasuk LPD di desanya yang sudah berjalan baik perlu terus digalakkan".

Menurut Nyoman Arta Wirawan sistem pengendalian internal di LPD Desa Pakraman Anturan dengan cara mengikuti aturan yang ada yaitu SOP (Standar Operasional Prosedur) dan dengan selalu memperhatikan koordinasi mengenai tugas masing-masing karyawan. Kemudian kas yang diterima dari berbagai kalangan (menabung, deposit, dan lainnya) tersebut dikelola dengan baik, dimana $75 \%$ dijadikan dalam bentuk kredit, 25\% dijadikan cadangan likuiditasnya, diantaranya $20 \%$ ditempatkan di bank dan 5\% dijadikan cadangan untuk pembiayaan-pembiayaan seperti biaya operasional. Selanjutnya pengawasan internal diawasi oleh Kelian Desa Adat. Pengawasan dilakukan kapanpun saja, tiap seminggu ataupun tiap sebulan dan pengawasan dilakukan sesuai dengan petunjuk teknis yang ada. Pamucuk LPD Desa Anturan Arta Wirawan didampingi Kelian Desa Pakraman Anturan Ketut Mangku, Senin (12/11), mengatakan

"Keberhasilan dalam mengelola usaha tidak lepas dari komitmen pengurus, badan pengawas, dan warga sebagai nasabah LPD. Selain itu, upaya pembinaan dalam meningkatkan kinerja sumber daya manusia (SDM), sehingga LPD yang dipimpinnya itu sukses membangkitkan perekonomian di Desa Anturan."

Dengan adanya pengendalian internal terhadap pengelolaan kas yang baik, maka dapat mempengaruhi laporan keuangan di LPD Desa Anturan menjadi lebih baik pula. Dengan adanya laporan keuangan yang baik ini LPD Desa Pakraman Anturan mendapatkan pringkat 10 besar LPD sehat di Bali.

\section{Simpulandan Saran Simpulan}

Dari penelitian ini dapat disimpulkam bahwa sistem pengendalian internal di LPD Desa Pakraman Anturan dengan cara mengikuti aturan yang ada yaitu SOP (Standar Operasional Prosedur) dan dengan selalu memperhatikan koordinasi mengenai tugas masing-masing karyawan. Kemudian kas yang diterima dari berbagai kalangan (menabung, deposit, dan lainnya) tersebut dikelola dengan baik, dimana $75 \%$ dijadikan dalam bentuk kredit, $25 \%$ dijadikan cadangan likuiditasnya, diantaranya $20 \%$ ditempatkan di bank dan $5 \%$ dijadikan cadangan untuk pembiayaan-pembiayaan seperti biaya operasional. Selanjutnya pengawasan internal diawasi oleh Kelian Desa Adat. Pengawasan dilakukan kapanpun saja, tiap seminggu ataupun tiap sebulan dan pengawasan dilakukan sesuai dengan petunjuk teknis yang ada. Dengan adanya pengendalian internal terhadap pengelolaan kas yang baik, maka dapat mempengaruhi laporan keuangan di LPD Desa Anturan menjadi lebih baik pula. Dengan adanya laporan keuangan yang baik ini LPD Desa Pakraman Anturan mendapatkan pringkat 10 besar LPD sehat di Bali.

\section{Saran}

Kami dari pihak peneliti ingin memberikan saran dan masukan yang mungkin berguna bagi LPD Desa Pakraman Anturan yaitu pertahankan atau tingkatkan lagi sistem pengendalian internalnya dan lakukan pembinaan secara rutin, agar tetap dijuluki sebagai LPD sehat. 


\section{DaftarPustaka}

BaliPost. 2018. LPD Desa Anturan Masuk 10 Besar LPD Sehat Di Bali. Dalamhttp://www.balipost.com/news/2018/11/13/61072/LPD-Desa-Anturan-Masuk10...html. Diakses pada 8 Januari 2019.

CourseHero. TT. 2 Pengertian Fungsi Tujuan dan Bidang Usaha LPD 21. Dalam https://www.coursehero.com/file/p487ras/2-Pengertian-Fungsi-Tujuan-dan-BidangUsaha-LPD-21-Pengertian-LPD-Lembaga/. Diakses pada 11Januari 2019.

Dian, Sutrisna Giriama Kadek. 2015. Evaluasi Sistem Pengendalian Internal Pada Pemberian Kredit Di Lembaga Perkreditan Desa (LPD) Sudaji. E-Jurnal Undiksha S1 Ak Universitas Pendidikan Ganesha. Vol.3, No.1. Diakses pada 14 Januari 2019.

Hambali, Moh Rusdiana. 2012. Pengertian Kas. Dalam https://administrasiperkantoran1.wordpress.com/2012/08/29/pengertian-kas/.

Diakses 12 Januari 2019.

Jejakakuntansi.net. 2017. Pengertian, Tujuan dan Unsur-Unsur Pengendalian Intern. Dalam http://www.jejakakuntansi.net/2017/09/pengertian-tujuan-dan-unsur-unsur.html. Diakses pada 11 Januari 2019.

Kenalinfo.web.id. 2016. Pengertian Data Primer dan Data Sekunder. Dalam https://www.kanalinfo.web.id/2016/10/pengertian-data-primer-dan-datasekunder.html. Diakses pada 11Januari 2019.

Mamuaju, Brejita. 2016. Analisis Efektivitas Penerapan Sistem Pengendalian Intern Terhadap Kinerja Instansi Pemerintah Di Dinas Pendapatan Kota Manado. Jurnal EMBA. Dalam https://ejournal.unsrat.ac.id/. Diakses pada 14 Januari 2019.

Maruf, Sandi. TT. Tujuan, Unsur dan Pengertian Sistem Pengendalian Intern.Dalamhttps://www.akuntansilengkap.com/akuntansi/tujuan-unsur-danpengertian-sistem-pengendalian-intern/. Diakses 12 Januari 2019.

MR.Soery. 2008. Lembaga Perkreditan Desa. Dalam http://soepayam.blogspot.com/2008/12/lembaga-perkreditan-desa.htm. Diakses 12 Januari 2019.

NN. 2017. Pengertian Kas Menurut Para Ahli. Dalam https://pengertianmenurut2.blogspot.com/2017/08/pengertian-kas-menurut-para-ahli.html. Diakses 12 Januari 2019.

Novitasari, Esterina. 2016. Sistem Pengendalian Intern Penerimaan Kas pada PD BPR BKK Karangmalang Cabang Sragen Kota. Tugas Akhir. Dalam https://eprints.uns.ac.id/. Diakses pada 14 Januari 2019.

Putri, Advionika Resy Bella. 2017. Evaluasi Pengendalian Internal Pengeluaran Kas Dana Bantuan Operasional (BOS) Studi Kasus pada SMKN 1 Yogyakarta. Skripsi. Dalam repository.usd.ac.id/. Diakses pada 14 Januari 2019.

Seputarpengetahuan.co.id. 2017. 15 Pengertian Sistem Pengendalian Intern Menurut Para Ahli Terlengkap. Dalam https://www.seputarpengetahuan.co.id/2017/11/pengertiansistem-pengendalian-intern-menurut-para-ahli.html. Diakses pada 11 Januari 2019.

Simamurung, Mario Caesar Piet. 2015. Analisis Pengendalian Penerimaan dan Pengeluaran Kas pada PT. Manado Media Grafika. Jurnal EMBA. Vol. 3, No.4. Dalam https://media.neliti.com/. Diakses pada 14 Januari 2019. 
Zamzami, Faiz \& Ihda Arifin Faiz. 2015. Evaluasi Implementasi Sistem Pengendalian Internal : Studi Kasus pada Sebuah Perguruan Tinggi Negeri. Jurnal Akuntansi Multiparadigma. Vol.6, No.1. Dalam jamal.ub.ac.id. Diakses pada 14 Januari 2019. 